\title{
New generation white clovers for United Kingdom farming systems
}

DR Woodfield ${ }^{1}$, JL Ford $^{1}{ }^{1}$, MZZ Jahufer ${ }^{1}$, D Johnston $^{2}$

${ }^{1}$ AgResearch Grasslands, Private bag 11008, Palmerston North, New Zealand

2 Dept. of Agriculture and Rural Development, Loughgall, Northern Ireland

Abstract. White clover is used worldwide to improve the nutritive value of pastures and is an increasingly important component of environmentally-sustainable grassland ecosystems. In 1991, a white clover breeding program involving two New Zealand companies (AgResearch and Midlands Seed) and a European company (Barenbrug), was initiated to develop new varieties for agricultural systems in the United Kingdom. This collaborative international program has been very successful with three improved varieties, Crusader, Barblanca and Makuri, being released and listed in the United Kingdom. The improved persistence and productivity of these varieties has enabled them to secure a significant share of the UK proprietary seed market. In particular, the medium-leaved Crusader produces at least 30\% more DM than any other small or medium-leaved white clovers in UK Recommended List trials. Changes in agricultural subsidies within the EU Common Agricultural Policy and the growing pressure to use environmentally sustainable agricultural practices should increase demand for new generation white clover varieties that can maximise both pasture production and animal productivity.

\section{Introduction}

White clover is used worldwide to improve the grazing value of pastures in temperate animal production regions and to provide low-cost nitrogen from nitrogen fixation. It is also increasingly seen as an important component of environmentally-sustainable grassland ecosystems because of its persistence under grazing, its ability to improve soil structure and its potential to reduce methane emissions.

Traditionally the UK is the second largest market for white clover seed in Europe. New Zealand-bred white clovers have been extensively used in the UK with the public variety Grasslands Huia having dominated the world white clover seed market for 40 years due to low seed price. In 1991, a white clover breeding program involving two New Zealand companies (AgResearch and Midlands Seed) and a European company (Barenbrug), was initiated to develop new varieties that were better adapted to UK agricultural systems. This brought together the extensive agronomic testing network of Barenbrug, the breeding expertise and genetic resources of AgResearch and the seed production capability of Midlands Seed.

This paper summarises the agronomic performance of white clover varieties and breeding lines that have been bred for the UK, and includes results from independent National List trials throughout the UK.

\section{National list testing}

An initial gene pool of 100 breeding lines that had been developed through intensive selection under grazing in New Zealand was evaluated at Wolfheze in the Netherlands and at Mas Grenier in Southern France beginning in 1991. Several experimental lines were identified and increased for wider agronomic testing including trials at Loughgall, Northern Ireland. The best lines were subsequently entered into United Kingdom National List trials, where they are evaluated under cutting as pure swards at 3 locations 
in England (Yorkshire, Shropshire and Devon), 1 location in Scotland (Aberdeen) and 1 location in Northern Ireland (Crossnacrevy). Three varieties (Crusader, Barblanca and Makuri) have achieved National List and/or Recommended List status since 2000.

Crusader in particular has had exceptionally high DM yield in UK National List trials run by NIAB (Figure 1), significantly outperforming all other small and medium-leaved varieties, and performing as well as the best large-leaved variety. Barblanca has also performed well in France and is on the French Recommended List.

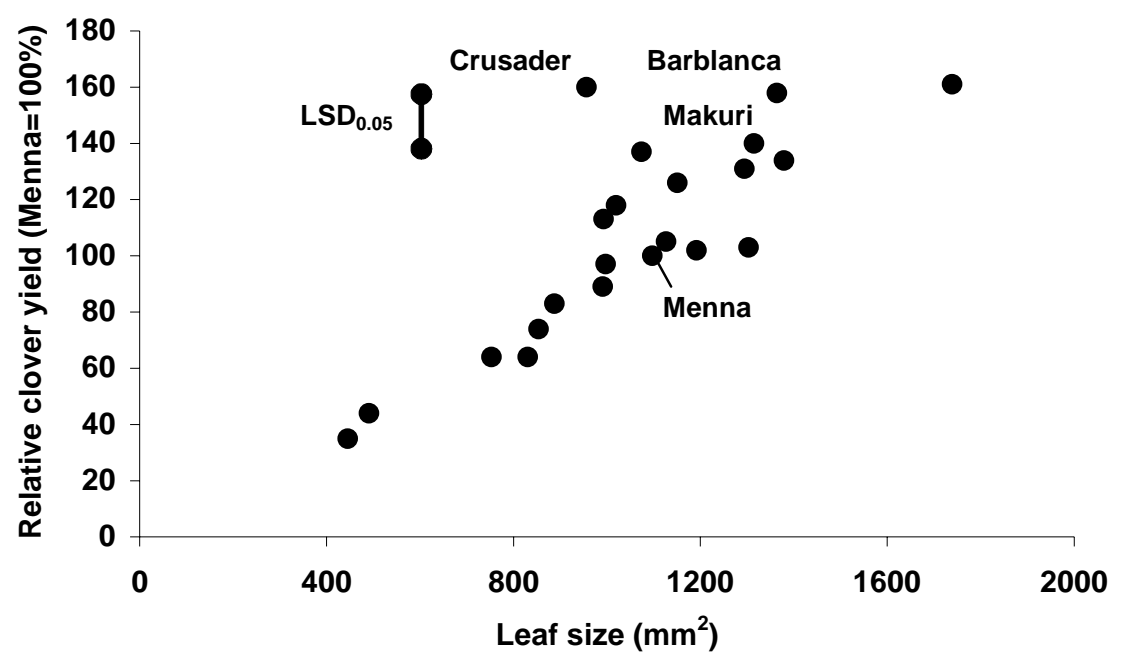

Figure 1. Clover yield in the third year of 22 white clover varieties in UK Recommended List trials relative to the yield of Menna (=100\%). (Adapted from NIAB 2003).

Table 1. Seasonal yield and leaf size of white clover varieties relative to the performance of Grasslands Huia in Northern Ireland (adapted from Gilliland 2005).

\begin{tabular}{lllll}
\hline \multirow{2}{*}{ Variety } & & \multicolumn{3}{l}{ Seasonal Dry Matter Yield (Huia =100\%) } \\
\cline { 3 - 5 } & $\begin{array}{l}\text { Relative leaf size } \\
\text { \% }\end{array}$ & $\begin{array}{l}\text { Spring } \\
\%\end{array}$ & $\begin{array}{l}\text { Summer } \\
\%\end{array}$ & $\begin{array}{l}\text { Autumn } \\
\%\end{array}$ \\
\hline Aberace & 37 & 14 & 79 & 47 \\
Demand & 75 & 104 & 99 & 96 \\
Crusader & 83 & 244 & 115 & 153 \\
Avoca & 84 & 127 & 120 & 154 \\
Aberherald & 86 & 108 & 120 & 134 \\
Menna & 95 & 107 & 119 & 128 \\
Aberdai & 96 & 113 & 127 & 115 \\
Chieftain & 99 & 201 & 152 & 163 \\
Huia & 100 & 100 & 100 & 100 \\
Alice & 118 & 149 & 133 & 141 \\
Barblanca & 120 & 206 & 126 & 165 \\
Aran & 149 & 144 & 134 & 173 \\
\hline
\end{tabular}

The new varieties have shown particularly strong cool-season growth with improved spring and autumn growth evident in results from Northern Ireland and Scotland National List trials (Tables 1 and 2). In Northern Ireland, Crusader and Barblanca have the best spring growth of any variety. Crusader has the best autumn yield of the smallleaved varieties, while Barblanca was among the top three varieties for autumn growth (Table 1). 
In Scotland, Crusader is the highest yielding variety in $2^{\text {nd }}$ and $3^{\text {rd }}$ harvest year irrespective of leaf size (Weddell 2004). Crusader is behind Avoca for spring DM yield but is the highest yielding variety in autumn, and is among the best in summer DM yield (Table 2). This extended growing season appears to be a key factor in improving the competitiveness of white clover in grass swards.

Table 2. Seasonal yield and leaf size of white clover varieties relative to the performance of Grasslands Huia in Scotland (Weddell 2004).

\begin{tabular}{lllll}
\hline \multirow{2}{*}{ Variety } & & \multicolumn{3}{l}{ Seasonal Dry Matter Yield (Huia =100\%) } \\
\cline { 3 - 5 } & $\begin{array}{l}\text { Relative leaf size } \\
\%\end{array}$ & $\begin{array}{l}\text { Spring } \\
\%\end{array}$ & $\begin{array}{l}\text { Summer } \\
\%\end{array}$ & $\begin{array}{l}\text { Autumn } \\
\%\end{array}$ \\
\hline Demand & 77 & 124 & 113 & 114 \\
Crusader & 83 & 161 & 134 & 175 \\
Avoca & 92 & 233 & 145 & 156 \\
Aberherald & 91 & 142 & 140 & 126 \\
Menna & 92 & 124 & 141 & 136 \\
Aberdai & 96 & 127 & 129 & 116 \\
Chieftain & 102 & 120 & 129 & 150 \\
Huia & 100 & 100 & 100 & 100 \\
Makuri & 113 & 138 & 127 & 127 \\
Barblanca & 118 & 124 & 117 & 139 \\
Alice & 119 & 140 & 138 & 139 \\
Aran & 157 & 134 & 134 & 168 \\
\hline
\end{tabular}

Breeding and testing of experimental synthetics in Northern Ireland

A minimum of 50 new breeding lines have entered evaluation biennially at Loughall since 1995. These include synthetic populations resulting from selection for persistence and productivity at Loughgall, and synthetics developed in continental Europe. Two managements, frequent and lax defoliation, have been imposed at Loughgall to reflect grazing and conservation managements that are commonly used in the UK. Frequent defoliation using a mower occurs every 10 days at $25 \mathrm{~mm}$, while plots under lax management are harvested every 40 days at 50mm during the growing season. Figure 2 shows the results from 30 breeding lines compared with three control cultivars (Aran, Crusader and Huia) over three years. These lines were visually scored on a 1-9 scale for clover yield and clover content prior to each defoliation. Crusader was the best of the control cultivars, although Huia also performed well under frequent defoliation. Conversely, Aran performed well under lax defoliation but performed very poorly under frequent defoliation. Three synthetics, ABM PxML, ABM MG88 and ABM MG DM performed strongly under both managements (Figure 2). ABM MG88 was the best line under frequent defoliation, while ABM PxML and ABM MG DM performed best under lax defoliation. Importantly these 3 synthetics were in the top $10 \%$ under both managements. ABM MG88 has been entered into UK, Irish and French National List trials, while ABM PxML is undergoing seed multiplication prior to entry into National List trials.

Jahufer et al. (2003) looked at the genetic relationship among 32 white clover varieties including Crusader and Barblanca. The genetic diversity among the varieties based on analysis of 39 microsatellite markers was consistent with their pedigree and geographical origin. For example, the varieties that contained a high proportion of Southern French germplasm (e.g. Crusader) clustered together. Barblanca, which contains more Spanish and Portugese parentage clustered with other varieties with 
predominantly Mediterranean parentage. Control varieties such as Aran, Demand, Huia and Milkanova clustered with varieties originating predominantly from Northern and Central Europe parentage.

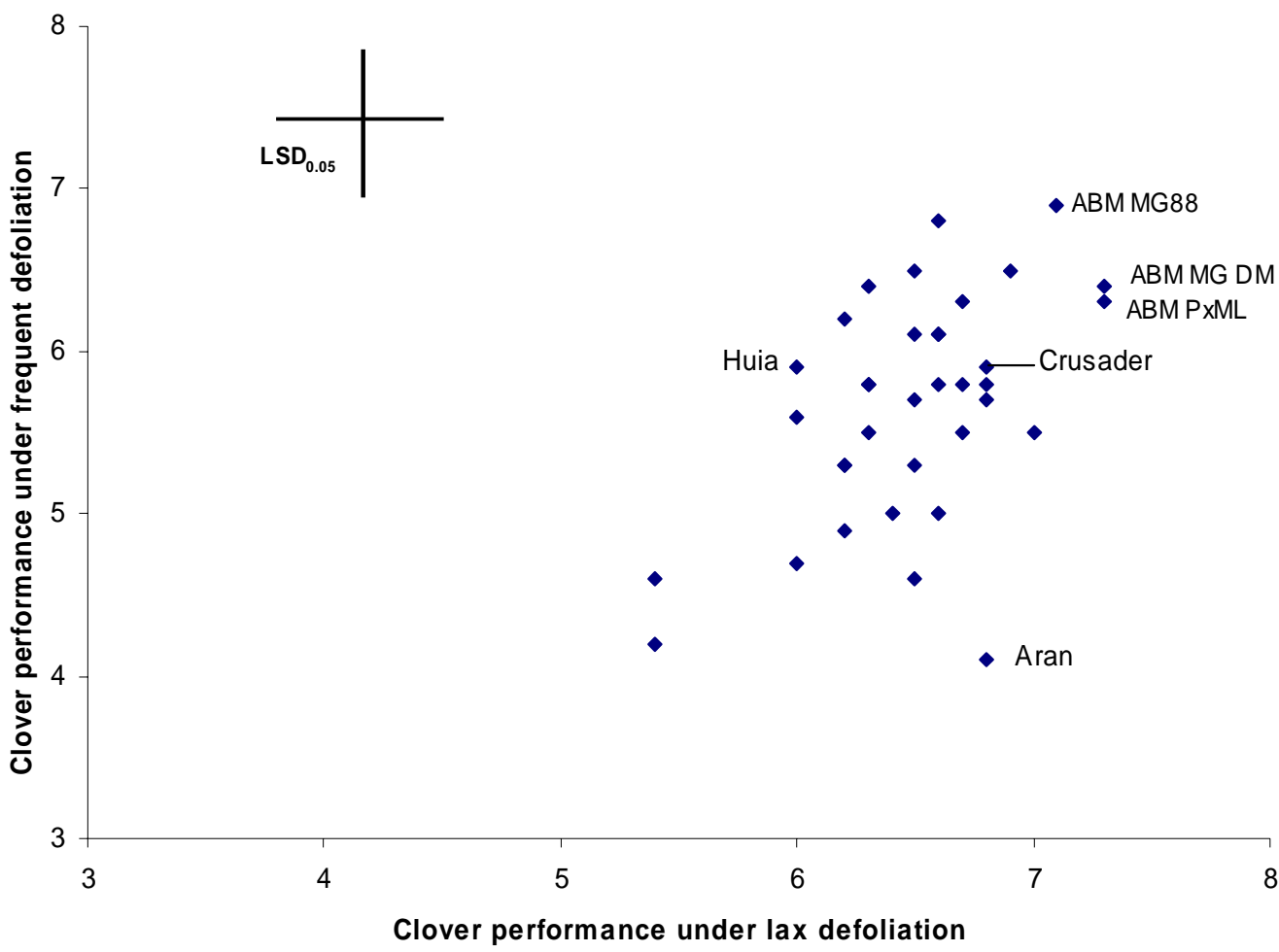

Figure 2. Performance of 30 breeding lines and 3 control cultivars under lax and frequent defoliation managements at Loughgall from 2002-2004.

Genetic improvements in white clover performance (Woodfield et al. 2001) have been shown to improve the productivity of beef cattle (J. Bouton et al. 2005) and sheep (Chapman \& Caradus 1997) in grazed pastures. There is similar potential in Europe to enhance livestock production and on-farm profitability given the strong performance of new persistent and productive white clover varieties such as Crusader. While most varieties have been bred for a specific climatic zone such as the UK, some varieties show much broader adaptation. New Zealand varieties have historically performed well in many parts of Europe, and data from sheep and cattle grazing indicates that both Crusader and Barblanca, which were developed for Europe also perform very well in New Zealand (Woodfield et al. 2001) and Australia (Woodfield unpubl. data). To avoid confusion with an annual ryegrass cultivar with the same name, Crusader is marketed in Australasia as Apex.

\section{Future opportunities}

New white clover varieties must undergo National List testing before they can be marketed in Europe, however, the evaluation system involving testing at a range of geographical locations under cutting, is expensive and slow. While the results provide an indication of climatic adaptation and pest and disease susceptibility, they do not adequately predict on-farm performance particularly under grazing. 
European breeding programmes target the National List testing system rather than the actual management systems used by European farmers. This focus does create an opportunity for varieties that can combine adaptation to grazing with acceptable performance in the testing system. Using germplasm selected under intensive grazing pressure has enabled AgResearch to develop varieties with acceptable performance in the testing system, while retaining strong persistence under grazing. Crusader, Makuri and Barblanca are the first varieties released using this approach.

Increasing international pressure to reduce both agricultural subsidies and the use of nitrogenous fertilisers is likely to generate significant demand for improved white clover varieties that can contribute to more sustainable legume-based grazing systems. Changes in agricultural subsidies within the EU Common Agricultural Policy and the growing pressure to use environmentally sustainable agricultural practices should increase demand for modern white clover varieties that can maximise both pasture production and animal productivity.

\section{References}

Bouton JH, Woodfield DR, Hoveland CS, McCann MA, Caradus, JR (2005) Enhanced survival and animal performance from ecotype derived white clover cultivars. Crop Science 45, 1596-1602.

Chapman DF, Caradus JR (1997) Effects of improved adapted white clover (Trifolium repens L.) germplasm on the productive properties of a hill pasture. New Zealand Journal of Agricultural Research 40, 207-221.

Gilliland TJ (2005) Grass and clover: Recommended varieties for Northern Ireland 2005/06. Department of Agriculture and Rural Development, Northern Ireland. 25pp.

Jahufer MZZ, Barrett BA, Griffiths AG, Woodfield DR (2003) DNA fingerprinting and genetic relationships among white clover cultivars. Proceedings of the New Zealand Grassland Association 65, 163-169.

Weddell JR (2004) Grass and clover varieties for Scotland 2004-2005. (Scottish Agricultural College, Edinburgh. 68pp).

Woodfield DR, Clifford PTP, Cousins GR, Ford JL, Baird IJ, Miller JE, Woodward SL, Caradus JR (2001) Grasslands Kopu II and Crusader: new generation white clovers. Proceedings of the New Zealand Grassland Association 63, 103-108. 